\title{
Can historians tell the truth? The Uluru Statement from the Heart and the quest for a new history
}

\author{
Ansel Wakamatsu \\ University of Technology Sydney, Faculty of Arts and Social Sciences, PO Box 123, Ultimo \\ NSW 2007, Australia. anselwaka@gmail.com
}

\begin{abstract}
Following the Uluru Statement from the Heart, historians are again tasked with 'telling the truth' about past human rights abuses in Australia. However, I argue that such a demand is too simplistic, and it is better to understand historians as producers of impermanent historical narratives which are embedded in public memory through the historian's discursive authority and the authority of a supporting truth commission.
\end{abstract}

Key words: Truth commission; truth-telling; Aboriginal history; public memory; discourse

\section{Introduction}

On May 26, 2017, the Uluru Statement from the Heart was endorsed by a constitutional convention of 250 Aboriginal and Torres Strait Islander delegates. The document outlined the most meaningful forms of constitutional recognition which Aboriginal and Torres Strait Islander people sought. Importantly, there was a call for a Makarrata Commission, which would 'supervise a process of agreement-making between governments and First Nations and truthtelling about our history' (Referendum Council 2017, p. i). It is this call for 'truth-telling' which will be assessed in this essay. More specifically, I will be analysing the potential role of the historian in an Australian truth commission, and the way historians are able to establish truth in the public sphere. But first, a definition of 'the truth' is in order. The term, 'the truth', is inherently problematic as it implies an absolute and singular legitimate representation of the past.

Copyright 2019 by the author. This is an Open Access article distributed under the terms of the Creative Commons Attribution 4.0 Unported (CC BY 4.0) License (https://creativecommons.org/licenses/by/4.0/), allowing third parties to copy and redistribute the material in any medium or format and to remix, transform, and build upon the material for any purpose, even commercially, provided the original work is properly cited and states its license.
}

NEW: Emerging scholars in Australian Indigenous Studies is a Student Journal from UTS ePRESS showcasing outstanding student works. 
Therefore, 'the truth' is an unproductive concept to apply to public truth-telling as it ignores the multitudinous and often contradictory personal accounts of a nation's history. Therefore, when referring to the idea of truth, I will be using the terms like 'truths' or 'a truth' to reflect the pliable nature of the concept. I argue that historians cannot 'tell the truth' about the past, but they can authenticate certain historical narratives which allows those narratives to be understood as 'truth' in public memory.

To complicate matters further, this essay will also be assessing the interplay between three types of truths which are produced through the work of a truth commission and through historical scholarship. Firstly, there are personal truths: individually embodied convictions and perspectives (Posel 2007). Secondly, there are forensic truths: the 'totality of corroborated facts about human rights violations' (Bakiner 2015). Thirdly, there are historical truths: the incorporation of these facts 'into explanations about conflict onset, patterns of violations, and their consequences' (Bakiner 2015).

The first section of this essay will attempt to define truth commissions and explore the potential scope of an Australian truth commission. The second section of the essay will argue that historians do not 'tell the truth' about the past, but are involved in a process of knowledge production wherein 'truths' are circulated and accepted in historical discourse because historians are recognised as discursive authority. Therefore, it is imperative to include historians, either directly or indirectly, in any future truth commissions in Australia as they are uniquely positioned to navigate personal accounts, assess forensic facts, and establish historical narratives which are seen as robust and legitimate.

\section{Discourse and truth commissions}

Having defined 'truth', let us now proceed to 'truth commissions'. A truth commission is a body that is 'set up to investigate a past history of violations of human rights in a particular country' (Wolman 2013). Elaborating further, Bakiner (2015) states that truth commissions:

\footnotetext{
Make a strong claim in favour of remembrance and truth as the precondition of...healing, reconciliation, and peace-building. Furthermore, truth commissions are sponsored by governments...In other words, their verdict on history carries the promise of official endorsement.
}

The purpose of a truth commission is to, in the broadest sense, create a collective history and national memory. Commissions interpret data (forensic truth) and contextualise individual stories (personal truth) to apply those elements to a broader historical narrative (historical truth). Truth commissions are uniquely positioned to overturn or shift public memory through a highly visible 
process that is state-sanctioned and involves high-level commissioners who often serve in state institutions or academies. In Foucauldian terms, the truth commission would constitute a discursive authority within the discourse of national history (Hall 1997, p.49), and thus lend credence to the versions of history that they produce. Foucault emphasizes the inextricable link between authority and truth, in that 'the truth' is simply knowledge that is produced by an authority and regulates the conduct of others (Hall 1997, p.49). For example, the National Inquiry into the Separation of Aboriginal and Torres Strait Islander Children from Their Families catalysed the emergence of the Stolen Generations truth in public discourse, regulating the way Australian history is taught in the 21 st century. I should note that although the Inquiry is technically not a commission, it still serves as a close equivalent in Australia as it constitutes a comprehensive, reconciliatory process through the act of historical investigation (Attwood 2001, p. 184). The Stolen Generations narrative was not merely told; it had to be produced by mapping personal truths to a larger historical truth which demonstrated a pattern of systematic human rights abuses. This information was then disseminated through scholarship and broadcast through a public truth-telling process. Much like historians, truth commissions operate on the same principle of knowledge production, leveraging authority to introduce narratives of human rights abuses in public memory. However, to understand how commissions and historians may work together in the future to address the truth-telling demands outlined in the Uluru Statement, it is necessary to first explore the proposed functions of the Makarrata Commission.

\section{What will the Makarrata look like?}

The areas of investigation in the Makarrata Commission proposed in the Uluru Statement of the Heart are not properly defined yet, but there are preliminary suggestions. In the final report of the Joint Select Committee on Constitutional Recognition relating to Aboriginal and Torres Strait Islander Peoples (2018, hereafter referred to as Joint Select Committee), it was noted that the Regional Dialogues emphasized 'the true history of colonialism must be told'. More specifically, the topic of massacres, dispossession, stolen wages, ongoing injustices, discrimination, and intergenerational trauma were raised. However, the report states that truth-telling could also be about sharing Aboriginal and Torres Strait Islander culture and language with their communities. In historian Mark McKenna's (2018, p. 32) Quarterly Essay, he highlights a singular aspect of settler-Indigenous violence and brings the scope of a potential truth commission into sharper focus:

One "truth" above all others was referred to repeatedly: "What happened all across Australia: the massacres and the wars." More than any other aspect of Australian history since the British arrived in 1788, it was this truth that Indigenous Australians wanted told. 
The mechanics of the commission, like everything else in this discussion, are not formed, let alone legislated. However, early indications show two distinct ways in which truth-telling can occur: through local/regional processes, and through national processes. As an alternative to the national, hearing-centric truth-telling commission in South Africa, Appleby \& Davis (2018) advance a process of local truth-telling undertaken in conjunction with community groups. Exemplifying this model are processes like the commemorations at Myall Creek, where community groups erect memorials and listen to one another's experience of the massacre (McKenna 2018, p. 68). Similarly, community groups on the Sunshine Coast conduct seminars which combine research and storytelling to talk about past injustices like forced removals (Joint Select Committee 2018). The Makarrata Commission's role would not be to supersede these initiatives, but to 'provide support and resources to continue to facilitate and encourage such processes' (Appleby \& Davis 2018).

On the national level, the Makarrata Commission could collate, properly archive, and make public these local truth-telling activities (Appleby \& Davis 2018) to reveal a nationwide history of violence (McKenna 2018, p. 38). Other potential prerogatives of the Makarrata Commission are informing changes to the educational curriculum regarding Aboriginal and Torres Strait Islander history and establishing a 'Keeping Place', where cultural information, artefacts, knowledge and testimony is stored for future generations of Aboriginal and non-Aboriginal people (Joint Select Committee 2018). Clearly, there is a precedent for truth-telling in Australia, and sophisticated ideas regarding new truth-telling initiatives are already forming. However, previous case studies suggest that a historian's presence is invaluable when attempting to build and proliferate new narratives of colonial settlement, thus I posit that it is necessary to involve them in any future commission process.

\section{The role of the historian}

Historians have considerable influence over truth-making due to their positioning in scholarly institutions and access to communicative mediums like journals. Adding to a historian's discursive authority is their ability to collect oral testimonies and engage in archival work; in other words, engage in what is sanctioned as legitimate research within an academy. By placing individual experiences in patterns of institutional violations, historians both produce and define historical events (Attwood 2001, p, 190). The truths which historians produce have the potential to be further legitimised and embedded within a collective national memory through collaborating with truth commissions, as commissions express their own discursive authority. Therefore, historian and commission have the ability to work in tandem to disrupt the hegemony of readily-accepted truths in the public sphere. In Australia, this collaborative approach is best understood by assessing the work of historians Peter Read and Lyndall Ryan. 
Peter Read is an ANU professor and responsible for researching the many ways in which Aboriginal children were 'separated from their kin' by the state (Attwood 2001, p. 189). Read's research established the body of knowledge which later came to be known as the Stolen Generations. Accounts of separation were widespread but disparate, which meant there was no overarching historical truth to bind these experiences together. Read collected testimonies from Aboriginal communities, and his 'account gained authority by virtue of the fact that it was based upon and could readily be represented as scholarly research' (Attwood 2001, p. 189). Read unified these experiences under the name 'the Stolen Generations', demonstrating how the act of naming a historical event is integral to the production of the event in public memory.

As the Stolen Generations' truth spread through public discourse, calls for an inquiry increased. The findings of the Inquiry, which concluded in 1997, 'had been heavily influenced by oral and written testimony that...organisations, especially Link-Up, had presented to the Inquiry' (Attwood 2001, p. 205). Link-Up was the organisation which Read and co-director Coral Edwards formed to connect separated Indigenous children back with their families. Link-Up sought to tie child separation with genocide, a claim which the Human Rights and Equal Opportunity Commission later backed. Evidently, Read's historical scholarship played a large part in establishing the impetus and agenda of the Inquiry. In a reflection on the development of the Stolen Generations narrative, Read (2002) noted that the Bringing Them Home report reinforced the narrative of the Australian state separating Aboriginal and Torres Strait Islander children from communities with genocidal intent, and initially made the narrative a 'secure and accepted part of the national story'. However, Read also knew that the hegemony of the Stolen Generations truth was not guaranteed, and reflected on how he had to defend his scholarship as critics emerged to downplay the scope and impact of forced removal (Read 2002). This demonstrates that the authority of commissions and historians are not absolute, and thus the truths which they produce become a part of a larger body of truths which vie to define national memory.

Currently, a comparative figure to Peter Read is Lyndall Ryan, a University of Newcastle historian whose effort to map the massacres of Australia's colonial frontier has been highlighted by the Joint Select Committee (2018) as a model form of truth-telling. Ryan's map allows users to select sites of massacre and discover further details regarding the attack (The Centre for 21 st Century Humanities 2019). Ryan states that colonial frontier massacres are a largely underresearched topic, and furthermore, the general public 'seem to know very little of the violent encounters between colonists and Aboriginal people' (Joint Select Committee 2018). Ryan's contribution to public knowledge regarding frontier conflict is especially accessible, as it is free and easy to find online. The project's broad reach and publicity enables it to disrupt the dominant 'peaceful settlement' truth which defines public understanding of Australia's colonial history. 
Much like the Stolen Generations' scholarship, the frontier massacre's scholarship 'has been local or regional in focus ... [and] Australians have yet to truly "see" the imprint of violence in their history on a national scale' (McKenna 2018, p. 39). Therefore, the Massacres Map project sees local histories bound together to form a national frontier history, elevated to a new position of visibility through a publicly available map hosted by an academic institution. Additionally, Ryan places a special emphasis on the term 'massacres' because the term 'genocide', in her experience, 'only makes people's eyes glaze over because it conjures images of the Holocaust and is perceived as a final judgement that ends conversations' (McKenna 2018, p. 38). As shown in the Stolen Generations example, the words used to name historical events have a profound effect on how the historical events are considered, as it clarifies the scope of what is being discussed. Ryan's goal of reshaping the public memory of settlement align well with the goals of the Makarrata Commission, and thus a deeper relationship between historian and commission should be encouraged.

\section{Conclusion}

So, can historians tell the truth about the past? I contend that historians are privileged authorities, uniquely positioned to produce truths which disrupt the collective memory of a body politic. Historians are vested with power because of three legitimising factors: connection to academic institutions which are themselves powerful sites of knowledge production; access to broad audiences; and ability to engage in research methods which are sanctioned by the academic institutions. This enables historians to introduce narratives which run counter to the prevailing truth of the day. In Australia, historians could use this power to contribute to the Makarrata Commission, if such a thing ever materialises. This truth-telling initiative would require expertise to map individual experiences and archival evidence to a broader pattern of human rights abuses, thus creating a historical narrative and a renewed understanding of Australia's past. Lyndall Ryan's online massacres map is already demonstrating how historians can aid the transition from personal memory to national history. If the Makarrata Commission does focus on frontier violence, such examples of historical scholarship will prove invaluable to reinforce new, difficult narratives to public discourse.

I will end this essay by expressing my hope for a truth commission, and for the intensive involvement of researchers and historians in that commission, whether or not they act as commissioners. I hope this because I think such an exercise will manifest an Australia which is further enlightened, engaged, and ultimately, unified. 


\section{Reference List}

Appleby, G. \& Davis, M. 2018, 'The Uluru Statement and the promise of truth', Australian Historical Studies, vol. 49, no. 4, pp. 501-509.

Arthur, P. 2009, 'How transition reshaped human rights: a conceptual history of transitional justice', Human Rights Quarterly, vol. 31, no. 2, pp. 321-367.

Attwood, B. 2001, 'Learning about the truth: the stolen generations narrative', in B. Attwood \& F. Magowan (eds), Telling stories: indigenous history and memory in Australia and New Zealand, Allen \& Unwin, Crows Nest, pp. 183-212.

Bakiner, O. 2015, 'One truth among others? Truth commissions' struggle for truth and memory', Memory Studies, vol. 8 no. 3, pp. 345-360.

Frow, J. 2005, 'Discourse', in T. Bennett, L. Grossberg \& M. Morris (eds), New Keywords: a revised vocabulary of culture and society, Blackwell Publishing, Malden, pp. 91-93.

Hall, S. 1997, 'The work of representation', in S. Hall (ed.), Representation: cultural representations and signifying practices, Sage Publications, London, pp. 13-75.

Ibhawoh, B. 2019, 'Do truth and reconciliation commissions heal divided nations?', The Conversation, viewed 22 June 2019, <https://theconversation.com/do-truth-and-reconciliationcommissions-heal-divided-nations-109925>.

Joint Select Committee 2018, Final Report, Parliament of the Commonwealth of Australia, Canberra.

McHoul, A. \& Grace, W. 1993, A Foucault primer: discourse, power and the subject, Melbourne University Press, Melbourne.

McKenna M. 2018, 'Moment of truth: history and Australia's future', Quarterly Essay, March (issue 69), pp. 1-86.

Posel, D. 2007, 'History as confession: the case of the South African Truth and Reconciliation Commission', Public Culture, vol. 20, no. 1, pp. 119-141. 
Read, P. 2002, 'Clio or Janus? Historians and the stolen generations', Australian Historical Studies, vol. 33, no. 118, pp. 54-60

Referendum Council 2017, Final report of the Referendum Council, Canberra.

The Centre for $21_{\text {st }}$ Century Humanities 2019, Colonial frontier massacres in Central and Eastern Australia 1788-1930, The University of Newcastle, Newcastle, viewed 22 June 2019, < https://c21ch.newcastle.edu.au/colonialmassacres/contact.php>.

Wolman, A. 2013, 'Looking back while moving forward: the evolution of truth commissions in Korea', Asian-Pacific Law and Policy Journal, vol. 14 no. 3, pp. 27-59. 